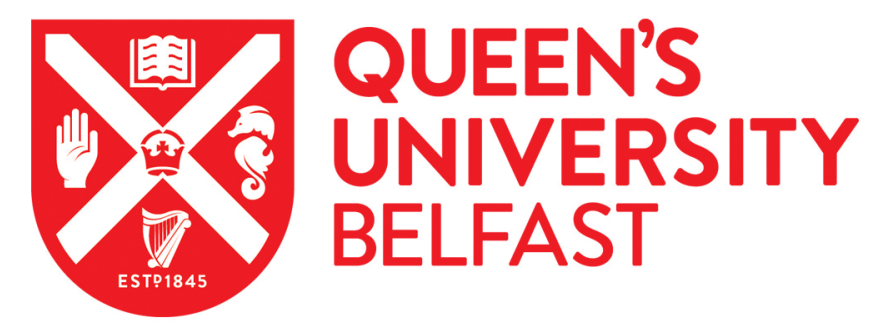

\title{
Political Violence and Adolescent Out-group Attitudes and Prosocial Behaviors: Implications for Positive Inter-group Relations
}

Taylor, L. K., Merrilees, C. E., Goeke-Morey, M. C., Shirlow, P., Cairns, E., \& Cummings, E. M. (2014). Political Violence and Adolescent Out-group Attitudes and Prosocial Behaviors: Implications for Positive Inter-group Relations. SOCIAL DEVELOPMENT, 23(4), 840-859. https://doi.org/10.1111/sode.12074

Published in:

SOCIAL DEVELOPMENT

Document Version:

Peer reviewed version

Queen's University Belfast - Research Portal:

Link to publication record in Queen's University Belfast Research Portal

Publisher rights

(C) 2014 John Wiley \& Sons Ltd

This is the accepted version of the following article: Taylor, Laura K.; Merrilees, Christine E.; Goeke-Morey, Marcie C.; Shirlow, Peter; Cairns, Ed; Cummings, E. Mark / Political Violence and Adolescent Out-group Attitudes and Prosocial Behaviors: Implications for Positive Inter-group Relations.

In: Social Development, Vol. 23, No. 4, 11.2014, p. 840-859, which has been published in final form at DOI: 10.1111/sode.12074

General rights

Copyright for the publications made accessible via the Queen's University Belfast Research Portal is retained by the author(s) and / or other copyright owners and it is a condition of accessing these publications that users recognise and abide by the legal requirements associated with these rights.

Take down policy

The Research Portal is Queen's institutional repository that provides access to Queen's research output. Every effort has been made to ensure that content in the Research Portal does not infringe any person's rights, or applicable UK laws. If you discover content in the Research Portal that you believe breaches copyright or violates any law, please contact openaccess@qub.ac.uk. 


\title{
Political Violence and Adolescent Out-group Attitudes and Prosocial Behaviors: Implications for Positive Inter-group Relations
}

Laura K. Taylor ${ }^{1}$, Christine E. Merrilees ${ }^{1}$, Marcie C. Goeke-Morey ${ }^{2}$, Peter Shirlow $^{3}$, Ed Cairns ${ }^{4}$ and E. Mark Cummings ${ }^{1}$

${ }^{1}$ University of Notre Dame

${ }^{2}$ The Catholic University of America

${ }^{3}$ Queen's University Belfast

${ }^{4}$ University of Ulster, Coleraine

\begin{abstract}
The negative impact of political violence on adolescent adjustment is well established. Less is known about factors that affect adolescents' positive outcomes in ethnically divided societies, especially influences on prosocial behaviors toward the out-group, which may promote constructive relations. For example, understanding how inter-group experiences and attitudes motivate out-group helping may foster inter-group co-operation and help to consolidate peace. The current study investigated adolescents' overall and out-group prosocial behaviors across two time points in Belfast, Northern Ireland $(\mathrm{N}=714$ dyads; $49 \%$ male; Time 1: $\mathrm{M}=$ 14.7, $\mathrm{SD}=2.0$, years old). Controlling for Time 1 prosocial behaviors, age, and gender, multi-variate structural equation modeling showed that experience with inter-group sectarian threat predicted fewer out-group prosocial behaviors at Time 2 at the trend level. On the other hand, greater experience of intra-group non-sectarian threat at Time 1 predicted more overall and out-group prosocial behaviors at Time 2. Moreover, positive out-group attitudes strengthened the link between intra-group threat and out-group prosocial behaviors one year later. Finally, experience with intra-group non-sectarian threat and out-group prosocial behaviors at Time 1 was related to more positive out-group attitudes at Time 2. The implications for youth development and inter-group relations in post-accord societies are discussed.
\end{abstract}

This research was supported by a NICHD grant 046933-05 to E. Mark Cummings. We would like to thank the many families in Northern Ireland who have participated in the project. We would also like to express our appreciation to project staff, graduate students, and undergraduate students at the University of Notre Dame and the University of Ulster.

Correspondence should be addressed to Laura K. Taylor, Department of Psychology, 200 Brownson Hall, University of Notre Dame, Notre Dame, IN 46556, USA. Email: ltaylo12@nd.edu 
Keywords: prosocial behavior; conflict; inter-group relations; resilience

\section{Introduction}

Relations between political violence and adolescent adjustment problems, including aggression and hostility, are well established (Keresteš, 2006; Merrilees et al., 2013; Qouta, Punamäki, Miller, \& El Sarraj, 2008). However, relatively less is known about inter-group factors that affect adolescents' positive behaviors in these contexts (Barber, 2009), including prosocial behavior toward out-group members (Tropp \& Mallett, 2011). In ethnically divided societies, understanding how inter- and intra-group experiences and attitudes motivate prosocial behavior across group lines, such as out-group helping (Stürmer \& Snyder, 2009; Vollhardt, 2009), may provide bases for fostering inter-group co-operation and ultimately consolidating peace (Kelman, 2008). The aim of the present study is to better understand conflicting findings on the impact of political violence on youth prosocial behaviors. To do so, it will tease apart adolescents' overall prosocial behavior from that directed toward out-group members. In addition, analyses will examine the reciprocal relations among these prosocial behaviors and different types of community threat and out-group attitudes. By differentiating between risk factors and adolescent outcomes over time, these findings may contribute to resolving conflicts that have spanned generations. Specifically, understanding the factors that promote resilience and prosocial psychosocial behaviors among youth born after a peace agreement may offer avenues for advancing peace processes (McEvoy-Levy, 2006).

Prosocial behaviors, or voluntary acts that benefit another without personal profits or external awards (Bar-Tal, 1976), are an example of positive youth adjustment that may have long-term implications for social justice and peace building. Yet, the research on the development of prosocial behaviors, such as helping, altruism, and social solidarity in contexts of political violence and inter-group tension is mixed (Stürmer \& Snyder, 2009). Some studies suggest a positive link between exposure to political violence and constructive prosocial engagement. Former child soldiers in Uganda were more likely to take on political leadership roles compared with nonabducted peers (Blattmann, 2009), Intifada exposure was related to greater activism among Palestinian youth (Barber, 2009), and during the civil war in Lebanon, separation from parents and witnessing violent acts were linked to increased levels of youth prosocial behaviors (Macksoud \& Aber, 1996). On the other hand, some research suggests a negative relation between experiencing inter-group conflict and youth prosocial acts. In Croatia, greater war stress related to fewer adolescent prosocial acts (Keresteš, 2006); in Sierra Leone, child soldiers who reported killing or injuring others showed a decrease in prosocial behaviors in the post-war context (Betancourt, Brennan, Rubin-Smith, Fitzmaurice, \& Gilman, 2010). In Northern Ireland, experience with sectarian, or inter-group, violence was directly related to fewer prosocial acts; however, non-sectarian antisocial acts, or intra-group threats from one's own community, predicted more prosocial behaviors in general (Cummings et al., 2010b).

These conflicting findings may reflect that experiences with different types of violence and threats may be related to different forms of positive adjustment. For example, whether threats were in the past during war or are part of the daily life in a post-accord period, may relate to divergent findings. In the current study, youth were born after the height of the contemporary violence in Northern Ireland, known as 


\section{Laura K. Taylor, Christine E. Merrilees, Marcie C. Goeke-Morey et al.}

the 'Troubles'. Therefore, this article extends past work focused on conflict experiences during war by focusing on experience with current, ongoing inter-group and intra-group conflict. In addition, this work extends studies that focus on out-group, rather than in-group, threat, and also complements experimental studies to examine relations among groups in the social ecological of the adolescents' lives (Nesdale, Durkin, Maass, \& Griffiths, 2005; Nesdale, Maass, Durkin, \& Griffiths, 2005). Finally, this study distinguishes between targets of positive youth outcomes. That is, rather than measuring only general prosocial behaviors that could be directed toward any target, the current study differentiates between overall prosocial behavior and positive acts directed at members of the 'other' group. Thus, the findings hold social significance, as out-group helping may be a key factor in fostering inter-group co-operation and serve as a building block for more peaceful relations in divided societies (Kelman, 2008; Stürmer \& Snyder, 2009).

\section{Promoting Out-group Prosocial Behaviors}

Altruism born of suffering is a theory that describes how experiencing adversity may enhance 'motivation to help other disadvantaged members of society, including outgroups' (Vollhardt, 2009). The theory specifically identifies the risk of intentional harm caused by other humans, which can threaten individuals and groups. Altruism, or the motivation to improve the well-being of others (Batson, Klein, Highberger, \& Shaw, 1995), can be enhanced because individual or collective pain increases perspective taking, heightens awareness of injustice more broadly, and promotes identification with victims of similar types of violence. Identifying with those who have suffered, even victims from the 'other' group, can influence inter-group helping behaviors (Stürmer, Snyder, \& Omoto, 2005).

Altruism born of suffering can also be related to cognitive shifts, such as perceived common fate, in settings of inter-group conflict (Staub \& Vollhardt, 2008). Conditions of high stress may inspire individuals to help others they perceive to share a common fate (Dovidio \& Morris, 1975; Vollhardt, 2009). Moreover, the 'salience of victimization may create the perception of shared group membership among individuals who suffered, giving rise to increased motivations to help other victims' (Vollhardt, 2009). For example, even in conflict settings where individuals would typically be categorized as an out-group member, the experience of mass violence provided the motivation to reconceptualize other victims as fellow sufferers (Penner, Dovidio, Piliavin, \& Schroeder, 2005). Thus, altruism born of suffering outlines how this cognitive shift toward shared membership based on perceived common fate between conflicting groups may underlie out-group prosocial behaviors (Reicher, Cassidy, Wolpert, Hopkins, \& Levine, 2006). Shared identities do not replace group membership, however, but rather redefine shared affiliations (Gaertner \& Dovidio, 2000), increasing motivations underlying prosocial behaviors, including toward out-group members.

\section{Constraining Out-group Prosocial Behaviors}

Another set of theories suggest that threat from the out-group may dampen or discourage the will to help members of that group. Social identity theory and selfcategorization theory (Tajfel \& Turner, 1979; Turner, 1982) explain that external threats and inter-group violence may lead individuals to help only those they perceive to be similar to themselves (Reicher, Hopkins, \& Condor, 1997). In emergency 
situations, individuals are more likely to help those with shared membership when in-group identity is salient (Levine, Prosser, Evans, \& Reicher, 2005). In the face of inter-group violence, the in-group may pull together (Taylor et al., 2011), and stronger social identity may promote individuals to work together for social and political change (Hammack, 2010). Thus, when individuals in tight-knit groups experience inter-group or sectarian violence, they should be more likely to help their own group (Coser, 1956), which may decrease the likelihood of reaching out to help members of the other group.

In settings of inter-group conflict, it is also possible that helping peers from the other group may be perceived negatively by the in-group. For example, children with stronger in-group commitment were more likely to negatively judge their peers who deviated from group loyalty norms (Abrams, Rutland, Ferrell, \& Pelletier, 2008). Following this 'black sheep' phenomenon (Abrams, Palmer, Rutland, Cameron, \& Van de Vyver, 2014; Marques, Yzerbyt, \& Leyens, 1988), deviant acts, such as acting prosocially toward out-group members, may lead to social sanctions or punishment (Pinto, Marques, Levine, \& Abrams, 2010). Co-operating with the other side may even put an individual at risk for greater intra-group threat or retaliatory punishment violence (Monaghan \& McLaughlin, 2006). In this context, fear of facing future intragroup threat may constrain adolescents from engaging in constructive behaviors and relations with out-group peers. However, not all antisocial behavior committed by the in-group is politically motivated; common crime or non-sectarian threats, such as substance misuse or gang membership, that occur within the boundaries of homogenous neighborhoods constitute another form of intra-group threat (van der Merwe \& Dawes, 2007). That is, youth may withdraw from community, decreasing the amount of prosocial acts, as they try to avoid antisocial behavior unrelated to historic conflict in Northern Ireland.

\section{Moderating the Risk Factors}

Moderation tests are particularly relevant to psychosocial processes that are not uniform across people (Cummings, Davies, \& Campbell, 2000). Within a risk and resilience framework, moderators can help to identify for whom and under what conditions the link between risks and outcomes is stronger. In a conflict environment, inter-group attitudes may moderate how different types of threat affect out-group prosocial behaviors in different scenarios (Dovidio, Gaertner, Shnabel, Saguy, \& Johnson, 2010). For example, when individuals hold negative inter-group perceptions or attitudes, they may be more likely to avoid inter-group interactions or respond with hostility or aggression toward the other group (Van Zomeren, Fischer, \& Spears, 2007). On the other hand, individuals with more positive out-group attitudes may be more likely to exhibit approach responses, such as prosocial behaviors, in inter-group settings (Butz \& Plant, 2011). However, compared with negative attitudes and prejudice (Rutland, Abrams, \& Levy, 2007), there is far less research on the role of positive inter-group evaluations (Stürmer \& Snyder, 2009; Tropp \& Mallett, 2011). Therefore, the role of inter-group attitudes and perceptions should be considered to better understand inter-group interactions and behaviors (Tropp \& Pettigrew, 2004), which have practical implications for social reconstruction in divided societies.

\section{Inter-generational Political Conflict}

During a post-accord period in protracted conflicts, the threat of on-going inter-group violence is well documented (Walter, 2004). Approximately 50\% of nations that 


\section{Laura K. Taylor, Christine E. Merrilees, Marcie C. Goeke-Morey et al.}

experience a civil war will experience renewed mass violence (Doyle \& Sambanis, 2000). Post-accord periods are also susceptible to new forms of criminal violence. However, the emergence of new threats, such as intra-group violence, receives far less attention in the changing post-accord environment. Following the peace agreements in South Africa and Northern Ireland, levels of common crime have increased as forms of political or sectarian violence declined (Police Service of Northern Ireland, 2011; Shirlow et al., 2012; van der Merwe \& Dawes, 2007). The impact of non-sectarian crime, or intra-group antisocial behaviors, has also been shown to have distinct effects on child adjustment and family processes (Cummings et al., 2010a, 2010b; Taylor et al., 2013). Other post-accord challenges, such as daily hardships and community acceptance, have also been found to have predictive power for youth outcomes independent of war experiences (Betancourt et al., 2010). Thus, multiple postaccord challenges should be considered to understand more fully adolescent social development.

Protracted or intractable conflict spans decades, and as such, requires peace-building plans on a similar scope. This 'decades-thinking' approach (Lederach, 1997), or long-term visions for a shared future, highlights the important role of youth in these processes. Yet, young people are often portrayed as helpless victims or violent perpetrators of conflict (Barber, 2009); their positive agency is often overlooked (McEvoy-Levy, 2006). If peace building entails fostering the structures and processes that redefine violent relationships into constructive and co-operative patterns (Lederach, 1997), then in settings of protracted conflict, young people must be engaged in establishing new patterns of more collaborative inter-group relations. Youth contributions, such as inter-group prosocial behaviors, may become particularly important in post-accords periods, where their absence in decision-making processes is particularly pronounced (McEvoy-Levy, 2006).

\section{Post-accord Northern Ireland}

The conflict in Northern Ireland has deep roots, with the most recent outbreak of sectarian violence occurring between 1968 and 1998, known as the Troubles. The dispute is largely a constitutional one, with the Unionists/Protestants wishing to remain part of the UK while the Republicans/Catholics aim for Ireland's reunification. Despite the 1998 Belfast Agreement, sectarian violence persists (Police Service of Northern Ireland, 2011). For example, in 2009 in Belfast, there were over 1200 sectarian incidents reported to the police, including acts of violence and damage to symbolic property such as churches. Yet, " "minor" forms of sectarianism, such as verbal abuse, harassment, visual displays, and graffiti' (Jarman, 2005) are largely under-reported in police data. Other studies have found that one in four adolescents is the victim of sectarian violence, and over $80 \%$ will experience sectarianism directly or indirectly (Byrne, Conway, \& Ostermeyer, 2005; McAloney, McCrystal, Percy, \& McCartan, 2009).

In addition to continued sectarianism, new forms of non-sectarian antisocial behavior and crime, or intra-group threats posed by in-group members, have grown, in part, due to the lack of social control by the paramilitaries (Monaghan \& McLaughlin, 2006). The increase in non-conflict related crime is not unique to Northern Ireland (Cox, 2000). In the context of post-accord Belfast, non-sectarian antisocial behavior is understood by local residents as being perpetrated by 'teenagers within their own communities' (Goeke-Morey et al., 2009). Because of the largely segregated nature of 
housing (Shirlow \& Murtagh, 2006), this conventional type of antisocial behavior, such as drinking, drugs, and home robberies, occurs within the boundaries of homogenous neighborhoods (Taylor et al., 2011). Along with the rise in conventional non-sectarian crime, there are also continued paramilitary-style assaults and shootings (see Belfast Telegraph, 2013). Thus, youth born after the Belfast Agreement experience both interand intra-group threat; both sources of stress should be considered to understand more completely the possible contributions of youth to peace building in Northern Ireland (Cummings, Goeke-Morey, Schermerhorn, Merrilees, \& Cairns, 2009).

\section{Current Study}

The current article examines how different types of post-accord threats, both intergroup and intra-group, and inter-group attitudes affect adolescent prosocial behaviors. Although overall prosocial behaviors may have benefits for society more broadly, out-group helping among youth may serve as a building block for future inter-group co-operation. Based on the previous research, it is hypothesized that the source of threat will have opposite effects on adolescent out-group helping; inter-group threat will decrease out-group prosocial behavior, whereas threat from one's own group will be linked to greater out-group prosocial behavior. We also hypothesize that this positive relationship will be stronger for youth who have positive attitudes toward the out-group.

\section{Method}

\section{Participants}

Mother/adolescent dyads $(N=714)$ were drawn from waves 4 and 5 of a longitudinal study on political violence, family processes, and youth adjustment in Belfast, Northern Ireland. A primary benefit of including mother and child reports includes decreasing shared method variance of a single reporter in survey data. Children were evenly balanced in terms of gender (49\% male) and were $14.66(S D=1.96)$ and $15.75(S D=$ 1.97 ) years old on average at each of the two time points. Mothers were $39.73(S D=$ $6.22)$ and $40.72(S D=6.32)$ years old on average, and $63 \%$ were single, whereas $37 \%$ were in two-parent households. Representative of the demographics of Northern Ireland, all participants were White, and 59\% and 41\% were from Protestant and Catholic backgrounds, respectively.

In the current analyses, between Time 1 and Time 2, there was $81 \%$ retention. Compared with families who remained in the study, youth that did not return reported greater experience with non-sectarian antisocial behavior $(t(519)=2.52, p<.05 ; M=$ $5.22, S D=6.63$ attrition; $M=3.68, S D=5.36$ retention), more positive out-group attitudes $(t(628)=2.48, p<.05 ; M=54.67, S D=28.49$ attrition; $M=48.21, S D=25.14$ retention), and greater overall prosocial behavior $(t(595)=2.17, p<.05 ; M=2.54$, $S D=.55$ attrition; $M=2.41, S D=.61$ retention). There were no significant differences among those who participated at Time 2 in child gender, age, experience with sectarian antisocial behavior, or out-group prosocial behaviors.

\section{Procedures}

Participants were recruited through stratified random sampling that identified approximately 35 families in each of 22 interfaced neighborhoods selected to minimize 


\section{Laura K. Taylor, Christine E. Merrilees, Marcie C. Goeke-Morey et al.}

socioeconomic status differences and represent a range of experiences with sectarian conflict. Interfaced areas are ethnically homogenous neighborhoods (greater than $90 \%$ Catholic or Protestant) that border a community in which the other group is the majority. Oftentimes, these interfaced areas are separated by 'peace walls' or major roads which further enhance segregated living patterns that extend into personal, educational, and professional life (Shirlow \& Murtagh, 2006). A common characteristic of interfaced areas is the lack of employment and livelihood opportunities. As such, all the study neighborhoods were working class and ranked in the bottom quarter of the most-socially deprived wards in Northern Ireland. Finally, there was a variety of experiences with political violence during the Troubles across the study areas. Neighborhoods were selected to include both higher and lower levels of historical political deaths, as well as variation in more recent levels of sectarian crime.

Children and mothers provided assent and consent prior to participating, and all data were collected through annual face-to-face surveys conducted in the participant's home by professionals from an established market research firm in Northern Ireland. Each interview lasted approximately $60 \mathrm{~min}$, and families received $£ 40$ at Time 1 and $£ 50$ at Time 2 for their participation. The Institutional Review Board at all participating universities approved the study.

\section{Measures}

Intra-group threat was measured using the non-sectarian antisocial behavior scale. This set of questions was designed to measure ordinary crime that was not related to the inter-group conflict. In the Belfast focus groups, participants clearly distinguished between sectarian and non-sectarian acts. For example, non-sectarian antisocial behaviors largely emerged after the peace accord, were committed by one's 'own' against the in-group, and occurred within rather than between homogenous communities (Taylor et al., 2011), and these qualitative data were confirmed by a two-wave pilot test (Goeke-Morey et al., 2009). These papers established the construct and predictive validity of this scale. In the current analyses, youth reported on how frequently in the last three months a series of items occurred using a 5-point scale from 0 (not in the last 3 months), 1 (once in the last 3 months), 2 (every month), 3 (every week), to 4 (every day). The seven-item scale included items such as drugs being used or sold, home break-ins, and robberies/muggings. Internal consistency measures the degree to which items aiming to measure the same general construct produce similar scores. Across the two waves, the Cronbach's $\alpha$ of the intra-group threat scale was .89 and .88 , respectively, indicating good correlations among the items.

Inter-group threat was assessed with the sectarian antisocial behavior, which was developed to assess awareness of sectarian, or inter-group, antisocial behaviors in the context of Belfast. Through qualitative focus groups and a two-wave pilot study (Goeke-Morey et al., 2009; Taylor et al., 2011), sectarian acts were identified as those that were rooted in the legacy of inter-group violence, were committed by 'them' against 'us', and frequently occurred along interface lines or boundaries. Using the same response scale as the intra-group, non-sectarian threat, the 12 items included events such as stones or objects thrown over walls, name calling by people from the other community, and deaths or serious injury caused by the other community (Cummings et al., 2010b). Cronbach's $\alpha$ for this scale was .94 at both time points.

Out-group attitudes were assessed by two separate questions that asked youth to indicate their 'overall feeling toward the Protestant/Catholic community' (Cairns, 
Kenworthy, Campbell, \& Hewstone, 2006). The scale represented a feeling thermometer, ranging from 0 (unfavorable) to 100 (favorable). This approach to distinguishing between in-group and out-group attitudes (Brewer, 2001) has been used previously in Northern Ireland and other settings of inter-group conflict (Hewstone, Rubin, \& Willis, 2002). Only out-group attitudes were in analyses; that is, if a child self-identified as Catholic, only the Protestant attitude score was used.

Prosocial behaviors were assessed by both overall and out-group-specific helping acts. Mothers reported on child overall prosocial behaviors using the prosocial with peers subscale of the Child Behavior Scale (CBS; Ladd \& Profilet, 1996). On a scale from 1 (doesn't apply), 2 (applies sometimes), to 3 (certainly applies), mothers responded to a seven-item scale measuring the degree to which their child shows a recognition of the feelings of others, co-operative with other children, and offers help or comfort when other children are upset. This subscale has been used to measure prosocial behaviors internationally (Meyer et al., 2011), and its construct and criterion validity have been established longitudinally through early adolescence (Ladd, Herald-Brown, \& Andrews, 2009). Cronbach's $\alpha$ were .96 and .95 across the two time points for overall prosocial behaviors.

Out-group prosocial behaviors were assessed following overall demonstration of empathy, co-operation, and concern, with a single-item question that asked, 'Thinking about all these things, how often did your child do these toward people from the OTHER community?' Mothers responded on a 5-point scale from 0 (never) to 4 (very often).

\section{Results}

Table 1 includes the means, standard deviations, and bivariate correlations for all manifest variables, controls, and a composite scale of overall prosocial behavior. AMOS Graphics 18 (Arbuckle, 2009) was used to model the following paths of interest using structural equation modeling (SEM). For the SEM model of direct and moderation effects, coefficients were derived using maximum likelihood which accurately estimates parameters under the assumption that data are missing at random. Overall model fit was assessed using a $\chi^{2} / d f$ index $\leq 3$, a Tucker Lewis Index (TLI) and comparative fit index $(\mathrm{CFI}) \geq .90$, and a root mean square residual $(\mathrm{RMSEA}) \leq .08(\mathrm{Hu}$ \& Bentler, 1999).

Significant correlations among indicator variables for overall prosocial behavior supported the creation of a latent variable. Little, Cunningham, Shahar, and Widaman (2002) review how parcels represent an aggregate-level indicator of two or more items, which increases the reliability and representativeness of the scale, as well as the stability of the factor solution (Little et al., 2002). Compared with individual indicators, analyses based on parcels are also more efficient, more normally distributed, and have smaller intervals between points on the scale. Using Little et al.'s (2002) technique for building parcels, a just-identified latent variable (i.e., with three parcels) model was selected because it represents a unique solution that optimally captures the relations among the items. The items-to-construct balance approach used the loadings of the seven-item indicators as a guide to form parcels. The factor loadings were ranked from highest to lowest; the three strongest items were assigned to 'anchor' each of the three parcels. The next highest three were added in inverted order, and the final of the seven items was added to the first parcel. A different number of items for each parcel is acceptable to achieve a reasonable balance (Little et al., 2002). The measurement 
848 Laura K. Taylor, Christine E. Merrilees, Marcie C. Goeke-Morey et al.

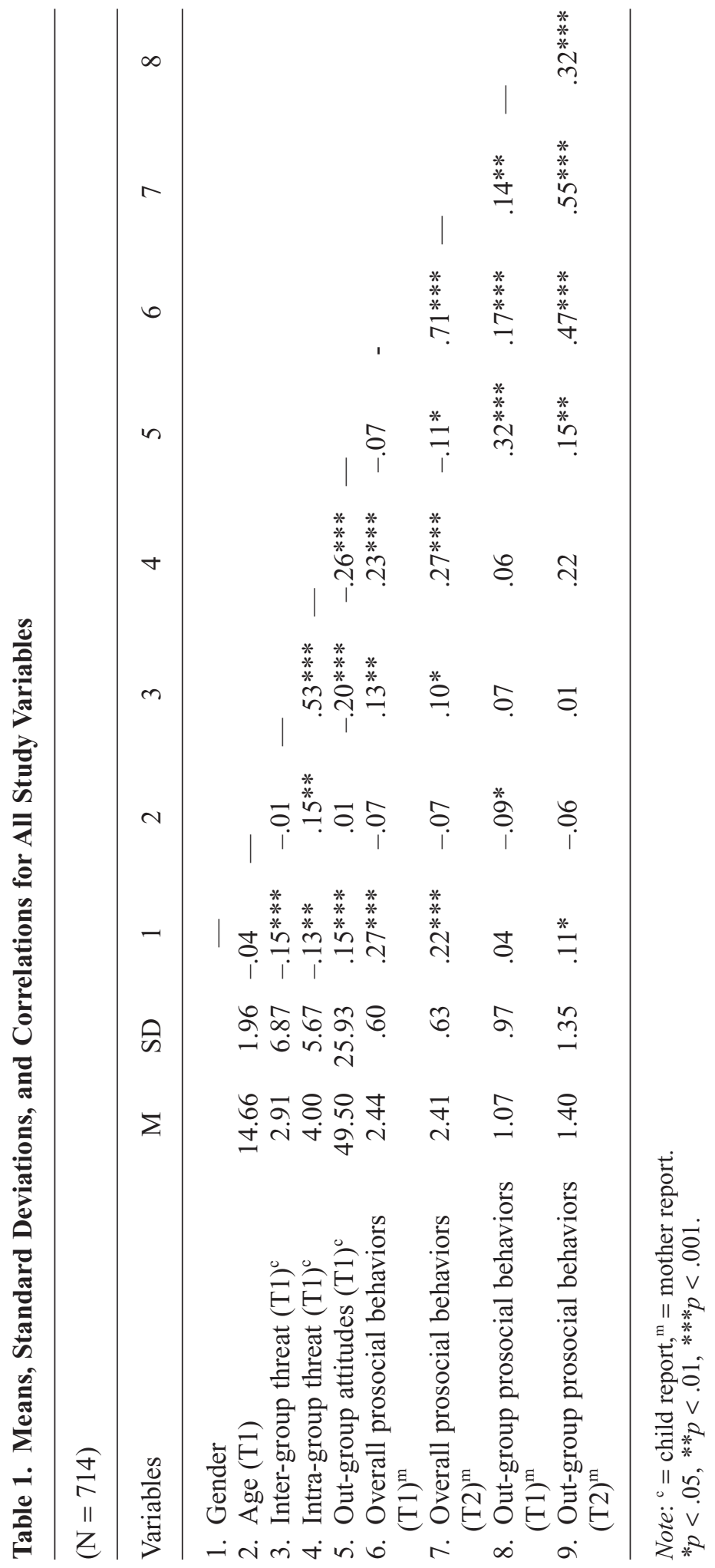


model for the latent constructs was tested by running a confirmatory factor analysis for prosocial behaviors at Time 1 and 2; parcels were forced to load on their given factor, and the prosocial latent variables at Time 1 and 2 were allowed to correlate yielding a model with acceptable fit $\left[\chi^{2}(8)=32.31, p<.05, N=714 ; \chi^{2} / d f=4.04\right.$; TLI $=.98$; $\mathrm{CFI}=.99$; RMSEA $=.07$ (CI: .04, .09)].

The main effects of the two risk factors, inter-group and intra-group threat at Time 1, on overall and out-group prosocial behaviors at Time 2 were examined, controlling for child gender and age at Time 1, as well as the auto-regressive controls for each of the outcomes of interest and the main effect of out-group attitudes at Time 1 . The interaction terms were created with the centered values of each type of threat and out-group attitudes, and then added to the model as exogenous predictors. To examine the possibility of reciprocal effects, a full cross-lagged model was tested; the relations among overall and out-group prosocial behaviors at Time 1 and inter-group and intra-group threat and out-group attitudes at Time 2 were also included. All exogenous variables and control variables were allowed to correlate with each other; error terms for the endogenous outcomes of interest were also allowed to correlate.

Figure 1 depicts the full cross-lag model, including both direct and moderation effects, that was tested; the fit for the overall model was good $\left[\chi^{2}(75)=244.95, p<.05\right.$, $N=714 ; \chi^{2} / d f=3.266$; TLI $=.93 ;$ CFI $=.97$; RMSEA $=.056$ (CI: .049, .064)]. Structural path estimates for the full model are in Table 2; for clarity, Figure 2 omits non-significant paths and stability estimates to present the significant paths of interest along with the standardized parameters. The control variable of child gender was significant; compared with males, female youth had higher overall $(\beta=.11, p<.01)$ and out-group $(\beta=.11, p<.01)$ prosocial behaviors. Age at Time 1 did not predict either type of prosocial behaviors. The autoregressive stability paths from Time 1 to Time 2 were also significant for each outcome of interest including overall prosocial $(\beta=.59, p<.001)$, out-group prosocial behaviors $(\beta=.26, p<.001)$, intra-group threat $(\beta=.54, p<.001)$, inter-group threat $(\beta=.61, p<.001)$, and out-group attitudes $(\beta=.57, p<.001)$. As a control, the main effect of out-group attitudes at Time $1 \mathrm{did}$ predict out-group helping at Time $2(\beta=.17, p<.001)$ but was not related to overall prosocial acts a year later.

Experience with sectarian, or inter-group, antisocial behavior was related to less out-group prosocial behavior at the trend level $(\beta=-.09, p<.10)$, and was not significantly related to overall prosocial acts a year later. Out-group attitudes did not moderate the pathway between sectarian threat and out-group helping. On the other hand, experience with non-sectarian, intra-group antisocial behavior was positively and significantly related to both overall prosocial behaviors $(\beta=.16, p<.001)$ and out-group helping $(\beta=.30, p<.001)$. Moreover, more positive out-group attitudes strengthened the link between intra-group threat and out-group prosocial behaviors $(\beta=.11, p<.01)$. This moderation effect is displayed in Figure 3; high and low out-group attitudes are graphed at one standard deviation above and below the mean.

Finally, the cross-lagged relations between overall and out-group prosocial behaviors at Time 1 and the other variables of interest at Time 2 were estimated. Greater mother report of out-group prosocial acts related to higher youth report of out-group attitudes one year later $(\beta=.12, p<.001)$ but did not significantly relate to greater intra-group threat over time. Taken together, these findings seem to suggest a positive feedback loop between out-group attitudes and behaviors. Moreover, the experience of intra-group threat appears to be a motivating factor to help out-group members, 


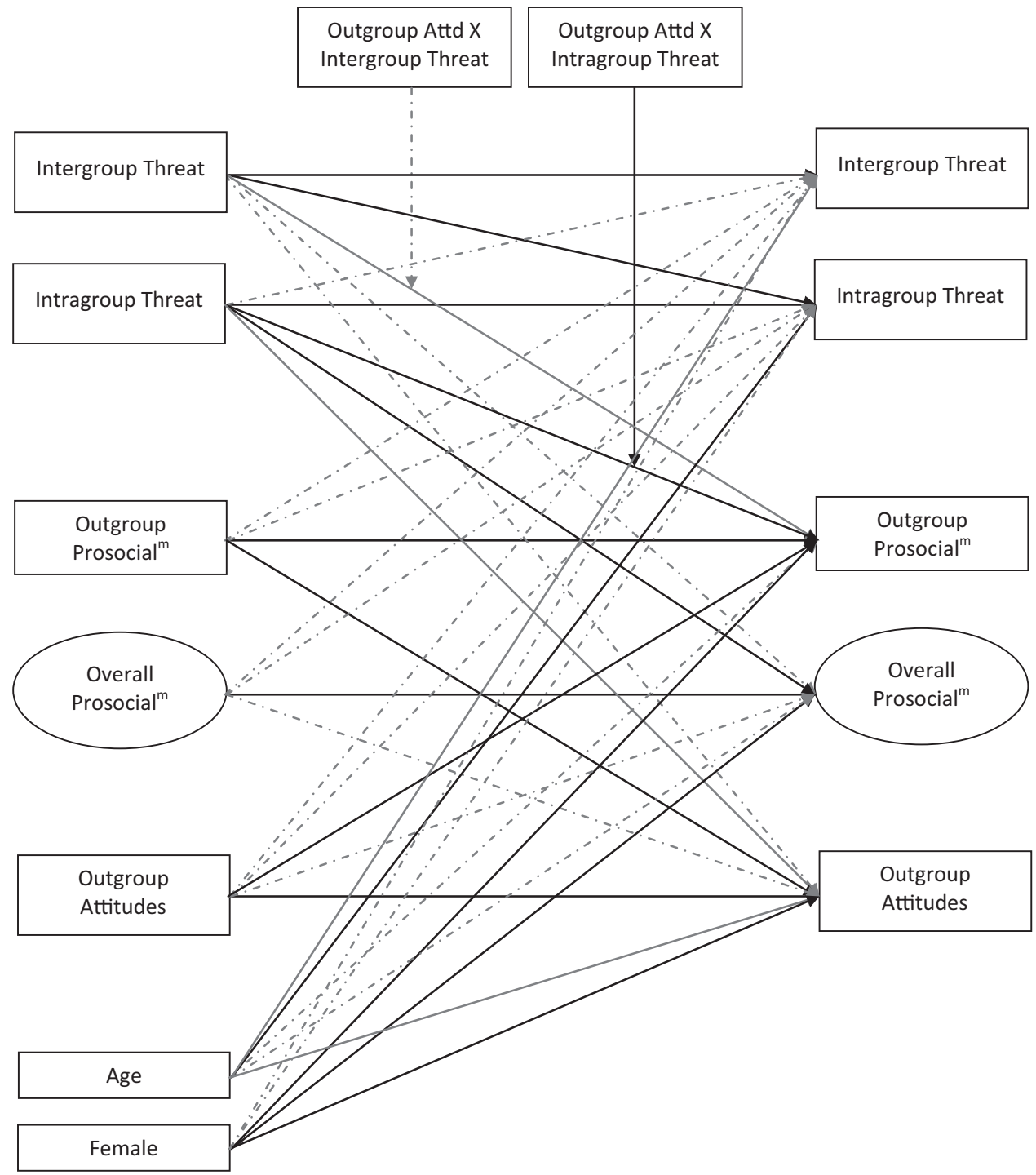

Figure 1. Complete Cross-lag Model, Including Both Direct and Moderation Effects, to Predict Overall and Out-group Prosocial Behaviors. All Variables are Child Report, Unless Denoted with ${ }^{\mathrm{m}}=$ Mother Report. Grey Dotted Lines Represent Non-significant Paths, Grey Full Lines Represent Trends, and Black Full Lines Represent Significant Paths. Exogenous Variables and Endogenous Outcomes Were Correlated, Respectively; Correlation Coefficients and Error Variances Were Omitted from the Model for Readability. ${ }^{\mathrm{t}} p<.10,{ }^{*} p<.05,{ }^{*} * p<.01, * * * p<.001$.

Model Fit: $\chi^{2}(75)=244.95, p<.05, \mathrm{~N}=714$; TLI $=.93$; CFI $=.97$; RMSEA $=.056$ (CI: $.049, .064)$. 
Table 2. Unstandardized, Standardized, and Significance Levels for Model in Figure 1 (Standard Errors in Parentheses; $N=714$ )

\begin{tabular}{|c|c|c|c|}
\hline Parameter estimate & Unstandardized & Standardized & $p$ \\
\hline \multicolumn{4}{|l|}{ Structural model estimate } \\
\hline $\begin{array}{l}\text { Overall prosocial }(\mathrm{T} 1) \rightarrow \text { overall } \\
\quad \text { prosocial }(\mathrm{T} 2)\end{array}$ & $.54(.04)$ & .59 & $<.001$ \\
\hline $\begin{array}{l}\text { Inter-group threat }(\mathrm{T} 1) \rightarrow \text { overall } \\
\text { prosocial }(\mathrm{T} 2)\end{array}$ & $.001(.004)$ & .007 & .88 \\
\hline $\begin{array}{l}\text { Intra-group threat }(\mathrm{T} 1) \rightarrow \text { overall } \\
\quad \text { prosocial }(\mathrm{T} 2)\end{array}$ & $.01(.004)$ & .13 & .004 \\
\hline $\begin{array}{l}\text { Out-group attitudes }(\mathrm{T} 1) \rightarrow \text { overall } \\
\quad \text { prosocial }(\mathrm{T} 2)\end{array}$ & $.01(.001)$ & .10 & .76 \\
\hline Female $\rightarrow$ overall prosocial (T2) & $.11(.04)$ & .11 & .004 \\
\hline Age $(\mathrm{T} 1) \rightarrow$ overall prosocial (T2) & $-.01(.01)$ & -.03 & .42 \\
\hline $\begin{array}{l}\text { Out-group prosocial }(\mathrm{T} 1) \rightarrow \text { Out-group } \\
\text { prosocial }(\mathrm{T} 2)\end{array}$ & $.36(.06)$ & .26 & $<.001$ \\
\hline $\begin{array}{l}\text { Inter-group threat (T1) } \rightarrow \text { Out-group } \\
\text { prosocial (T2) }\end{array}$ & $-.02(.01)$ & -.09 & .09 \\
\hline $\begin{array}{l}\text { Intra-group threat }(\mathrm{T} 1) \rightarrow \text { Out-group } \\
\text { prosocial }(\mathrm{T} 2)\end{array}$ & $.04(.01)$ & .30 & $<.001$ \\
\hline $\begin{array}{l}\text { Out-group attitudes (T1) } \rightarrow \text { Out-group } \\
\text { prosocial (T2) }\end{array}$ & $.01(.002)$ & .17 & $<.001$ \\
\hline Female $\rightarrow$ out-group prosocial (T2) & $.31(.11)$ & .11 & .006 \\
\hline Age (T1) $\rightarrow$ out-group prosocial (T2) & $-.03(.03)$ & -.05 & .29 \\
\hline $\begin{array}{l}\text { Ougroup attd X Intra-group threat } \rightarrow \\
\text { out-group prosocial (T2) }\end{array}$ & $.001(.001)$ & .11 & .01 \\
\hline $\begin{array}{l}\text { Ougroup attd X Inter-group threat } \rightarrow \\
\text { out-group prosocial (T2) }\end{array}$ & $.001(.001)$ & .04 & .42 \\
\hline $\begin{array}{l}\text { Inter-group threat }(\mathrm{T} 1) \rightarrow \text { inter-group } \\
\text { threat (T2) }\end{array}$ & $.61(.04)$ & .61 & $<.001$ \\
\hline $\begin{array}{l}\text { Intra-group threat (T1) } \rightarrow \text { inter-group } \\
\text { threat }(\mathrm{T} 2)\end{array}$ & $-.05(.06)$ & -.04 & .36 \\
\hline $\begin{array}{l}\text { Out-group attitudes (T1) } \rightarrow \text { inter-group } \\
\text { threat (T2) }\end{array}$ & $-.001(.01)$ & -.01 & .91 \\
\hline Female $\rightarrow$ inter-group threat (T2) & $-.27(.51)$ & -.02 & .60 \\
\hline Age (T1) $\rightarrow$ inter-group threat (T2) & $-.21(.13)$ & -.06 & .09 \\
\hline $\begin{array}{l}\text { Inter-group threat (T1) } \rightarrow \text { intra-group } \\
\text { threat }(\mathrm{T} 2)\end{array}$ & $.07(.03)$ & .11 & .014 \\
\hline $\begin{array}{l}\text { Intra-group threat (T1) } \rightarrow \text { intra-group } \\
\text { threat (T2) }\end{array}$ & $.44(.04)$ & .54 & $<.001$ \\
\hline $\begin{array}{l}\text { Out-group attitudes (T1) } \rightarrow \text { intra-group } \\
\text { threat (T2) }\end{array}$ & $.004(.008)$ & .02 & .61 \\
\hline Female $\rightarrow$ intra-group threat (T2) & $-.57(.37)$ & -.06 & .12 \\
\hline Age (T1) $\rightarrow$ intra-group threat (T2) & $.35(.09)$ & .15 & $<.001$ \\
\hline
\end{tabular}


Table 2. Continued

\begin{tabular}{lccc}
\hline Parameter estimate & Unstandardized & Standardized & $p$ \\
\hline $\begin{array}{l}\text { Overall prosocial (T1) } \rightarrow \text { out-group } \\
\quad \text { attitudes (T2) }\end{array}$ & $2.28(1.76)$ & -.06 & .11 \\
$\begin{array}{l}\text { Out-group prosocial (T1) } \rightarrow \text { out-group } \\
\quad \text { attitudes (T2) }\end{array}$ & $3.19(1.00)$ & .12 & .001 \\
$\begin{array}{l}\text { Inter-group threat (T1) } \rightarrow \text { out-group } \\
\quad \text { attitudes (T2) }\end{array}$ & $-.13(.16)$ & -.03 & .42 \\
$\begin{array}{l}\text { Intra-group threat (T1) } \rightarrow \text { out-group } \\
\quad \text { attitudes (T2) }\end{array}$ & $.39(.20)$ & .08 & .06 \\
$\begin{array}{l}\text { Out-group attitudes (T1) } \rightarrow \text { out-group } \\
\quad \text { attitudes (T2) }\end{array}$ & $.57(.04)$ & .56 & $<.001$ \\
$\begin{array}{l}\text { Female } \rightarrow \text { out-group attitudes (T2) } \\
\text { Age (T1) } \rightarrow \text { out-group attitudes (T2) }\end{array}$ & $5.37(1.86)$ & .10 & .004 \\
\end{tabular}

Note: $\chi^{2}(75)=244.95, p<.05, \mathrm{~N}=714 ; \mathrm{TLI}=.93 ; \mathrm{CFI}=.97 ; \mathrm{RMSEA}=.056$ (CI: .049, .064); Measurement model parameters available upon request from first author.

without carrying the risk of retaliation as measured in the current study. In addition, the experience of intra-group threat at Time 1 is related to more positive out-group attitudes at Time 2 at the trend level $(\beta=.08, p<.10)$. Modeling these alternative directional pathways helps to understand the order of effects of intra-group threat on out-group attitudes and prosocial behaviors for youth in a post-accord setting.

\section{Discussion}

The goal of the current study was to highlight positive youth outcomes that may have implications for inter-group relations. Prosocial behaviors were the outcome of interest because of the potential to foster inter-group co-operation if helping acts are extended to out-group members. Out-group attitudes were also considered as a possible moderator of the link between risk and behaviors one year later for adolescents living in Belfast, a setting of protracted conflict. Using two time points, and controlling for other relevant demographic variables, the analyses found that experience of inter-group antisocial behavior showed a trend toward decreasing out-group helping, whereas intra-group antisocial behavior was related to greater overall and out-group prosocial acts. The positive link between intra-group threat and out-group helping was even stronger for those youth who had more positive out-group attitudes. Moreover, both the experience of intra-group threat and out-group helping were linked to more positive out-group attitudes a year later. This set of findings makes an important contribution to the literature by differentiating between types of risk (inter-group vs. intra-group), as well as specifying the target of prosocial acts (overall vs. out-group). Examining these reciprocal effects over time for adolescents in a real-world setting of protracted conflict, the results suggest that programs which foster more positive out-group attitudes and provide opportunity for out-group helping may have promising implications for more constructive inter-group relations in Belfast.

Focusing on the type of threat and timing of measurement, this article helps to explain conflicting results surrounding prosocial outcomes in previous research on 


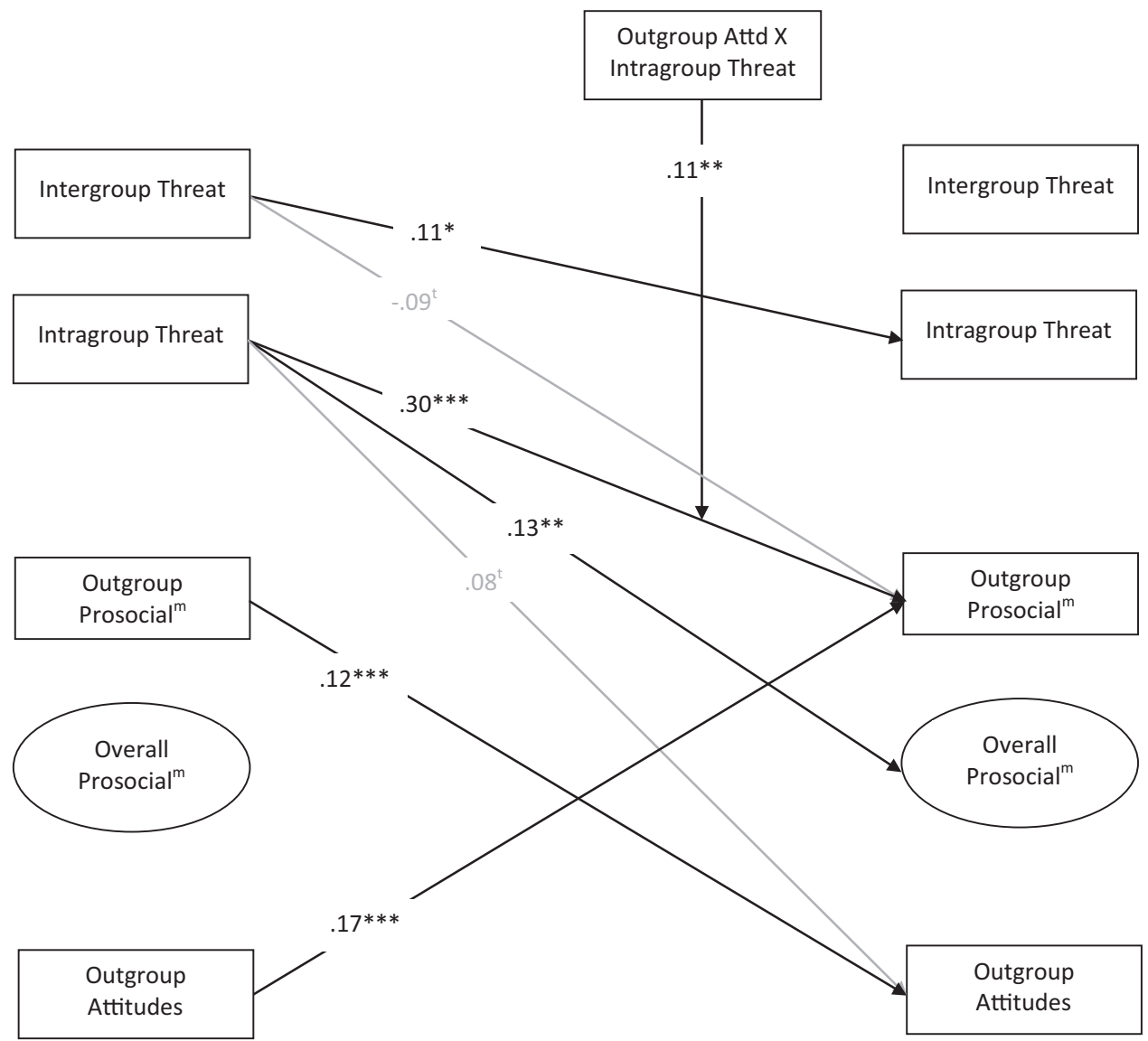

Figure 2. Simplified Cross-lag Model, Including All Significant Direct and Moderation Effects of Interest, Omitting Stability Parameters. As with Figure 1, All Variables Are Child Report, Unless Denoted with ${ }^{\mathrm{m}}=$ Mother Report. Grey Full Lines Represent Trends, and Black Full Lines Represent Significant Paths. Exogenous Variables and Endogenous Outcomes Were Correlated, Respectively; Correlation Coefficients and Error Variances Were Omitted from the Model for Readability. ${ }^{t} p<.10, * p<.05$, $* * p<.01, * * * p<.001$.

Model Fit: $\chi^{2}(75)=244.95, p<.05, \mathrm{~N}=714$; TLI $=.93 ; \mathrm{CFI}=.97$; RMSEA $=.056$ (CI: $.049, .064)$.

youth risk and resilience processes in settings of political violence. Altruism born of suffering may explain the positive link between intra-group threat and out-group helping; although future research is needed to test this variable as a mediating process. According to this theory, pain caused by intentional human harm may facilitate individuals to see new perspectives, including greater attention to overall injustice and perceiving a common fate with other victims. Reconceptualizing past rivals as fellow sufferers, a shared 'victim' identity links individuals across group memberships. With this shift, empathy and compassion for others may evoke greater helping behaviors. 


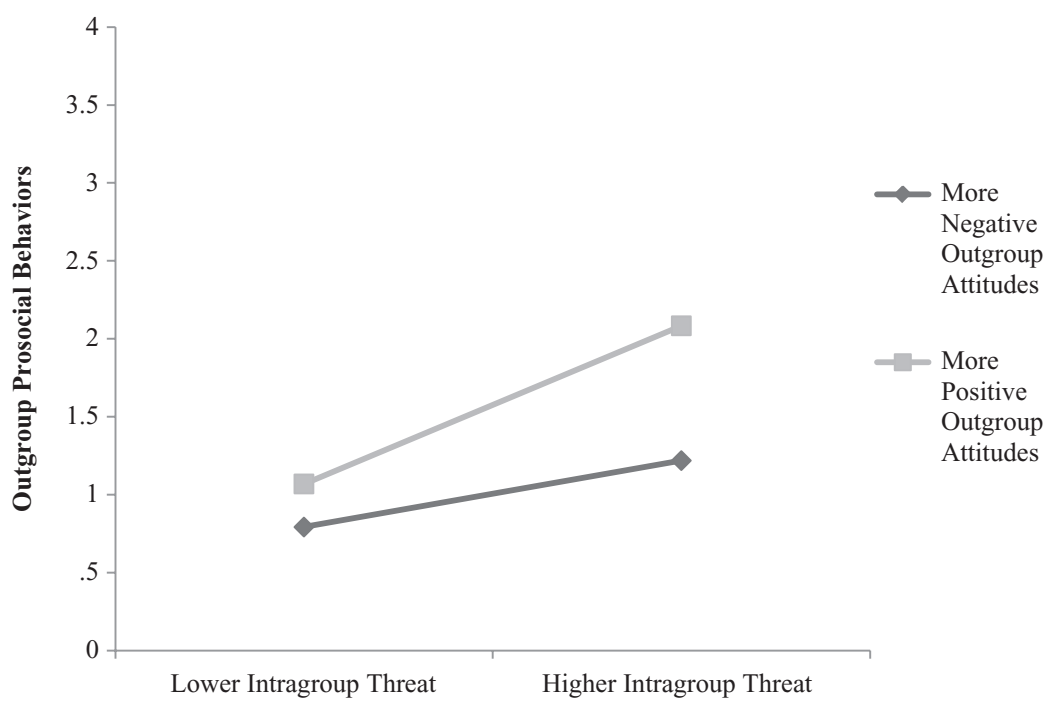

Figure 3. Interaction of Out-group Attitudes and Intra-group Threat, or Non-sectarian Antisocial Behavior, on Out-group Prosocial Behaviors. The Positive Relationship Between Intra-group Threat and Out-group Prosocial Acts Is Strengthened for Those Who Have More Positive Attitudes Toward the Out-group. Higher/Lower Out-group Attitudes Depicted at \pm 1 SD.

Inclusive victim consciousness, or recognizing the shared aspects of suffering, may also affect out-group attitudes. In this study, experience of intra-group threat predicted more positive out-group attitudes a year later. Moreover, positive inter-group attitudes may increase the possibility of approach responses which can facilitate prosocial behaviors (Butz \& Plant, 2011). The moderating role of positive out-group attitudes strengthened the relation between intra-group threat and greater out-group prosocial acts among adolescents in Belfast. At the same time, the reciprocal effect between these two variables was not significant; that is, helping the out-group at Time 1 did not significantly increase the experience of intra-group threat at Time 2 . This set of findings suggests that a positive feedback loop may be in effect; more positive behaviors predict more positive attitudes, while at the same time more positive attitudes lead to more positive behaviors. These relations appear to hold without being linked to greater experience with intra-group antisocial behavior for youth in Belfast.

Regarding the timing of measurement, the current study was conducted in a postaccord context. In this setting, the increase in non-sectarian or intra-group threat may motivate individuals to consider new possibilities not imagined during the Troubles. Bar-Tal and Halperin (2009) label this an 'unfreezing process' in which groups are presented with inconsistent or conflicting information that 'creates some kind of tension, dissonance, dilemma, or internal conflict, thereby stimulating people to move away from their previous stance and search for new information' (emphasis added). The emergence of intra-group antisocial behavior may function as this type of motivating factor, eroding perceived inter-dependence among in-group members (Flippen, Hornstein, Siegal, \& Weitzman, 1996), and encouraging individuals to consider alternative attitudes or behaviors. Thus, 'collective prosocial behavior benefitting out-group members may be particularly likely after suffering caused by members of the social 
in-group' (Vollhardt, 2009). With an eye toward the future, youth may be more open to the possibility of unfreezing the inter-group patterns that defined past sectarian conflict (Wallach, 2000).

By distinguishing between overall and out-group prosocial acts, this article attempts to challenge the portrayal of youth as perpetrators or helpless victims in times of conflict, and to recognize their agency in rebuilding relationships across group lines. Even in the face of continued inter-group violence, the findings provide insight on ways to promote inter-group co-operation among adolescents exposed to intra-group violence, particularly by promoting more positive out-group attitudes and providing opportunities for out-group helping. Promoting dual identity (i.e., attachment to a subgroup and a shared common group) through extended contact has been shown to improve children's attitudes toward out-group members (Cameron, Rutland, Brown, \& Douch, 2006). In Northern Ireland, the majority of young people who had participated in cross-community projects reported more favorable out-group attitudes (Schubotz \& Robinson, 2006). Future translational research should develop empirically informed programs that foster inter-group co-operation, promote prosocial behaviors, and foster positive out-group attitudes, which in turn may help to consolidate peace across group lines and in local communities.

Future research should also consider other constructive inter-group attitudes and behaviors, such as trust and forgiveness, and how these relate to attitudes toward peace for youth in Northern Ireland. Promoting positive out-group attitudes may be one avenue to promote out-group helping, but deepening trust may also improve intergroup behaviors over and above liking members of the other group (Tam, Hewstone, Kenworthy, \& Cairns, 2009). Inter-group forgiveness, a key component of long-term peace building, has also been related to empathy following inter-group contact (Tam et al., 2008). Trust and forgiveness among youth may further inter-group co-operation over time in situations of protracted conflict.

Two of the strengths of the current study include the inclusion of multiple reports to reduce method variance and the use of two time-points of data which allow for examination of change over time. Both of these elements increase the validity and reliability of the findings. Of course, additional changes could improve the study. First, peer or teacher reports of youth prosocial behaviors could reduce social desirability that may have influenced mothers' reports of the prosocial behaviors of their children. Peer reports may also reveal important social norms that could promote overall and/or out-group prosocial behavior (Chung-Hall \& Chen, 2010). Second, future research could investigate a more multi-dimensional construct of positive attitudes, such as affection, social ease, social closeness, and learning inspiration (Pittinsky, Rosenthal, \& Montoya, 2011). Third, out-group helping may not always be prosocial; some individuals may help in order to maintain social dominance by reaffirming a high status position (Nadler, Harpaz-Gorodeisky, \& Ben-David, 2009). The scales used in the current study, however, do not permit parsing out specific intentions from the prosocial behaviors themselves. Fourth, the intra-group threat scale, designed in response to mother's preoccupations about the safety and security of their families in Belfast (Taylor et al., 2011), largely included conventional forms of crime and antisocial behavior committed by in-group members. Future research should extend this more common or daily threat to include threats related to paramilitary punishment attacks or threats as well. Finally, to more fully test the role of altruism born of suffering as an explanatory theory, longitudinal meditational tests of this construct are needed. 
Addressing protracted conflicts necessitates a generational approach to peace building (Lederach, 1997). Thus, this article studies prosocial psychosocial outcomes among youth in a post-accord society. Given that young people may be mobilized in the escalation of violent conflict, their constructive contributions are often overlooked (McEvoy-Levy, 2006). Complementing previous research which aims to identify factors that constrain violent inter-group conflict, the goal of the current article was to focus on aspects of the social ecology that can contribute to positive social reconstruction in conflict-affected societies. The peace-building potential of youth may generalize to other post-accord contexts in which levels of intra-group violence and common crime are on the rise (van der Merwe \& Dawes, 2007). This article shifts the focus from youth as troublemakers to youth as peacemakers (McEvoy-Levy, 2006).

\section{References}

Abrams, D., Palmer, S. B., Rutland, A., Cameron, L., \& Van de Vyver, J. (2014). Evaluations of and reasoning about normative and deviant ingroup and outgroup members: Development of the black sheep effect. Developmental Psychology, 50, 258-270.

Abrams, D., Rutland, A., Ferrell, J. M., \& Pelletier, J. (2008). Children's judgments of disloyal and immoral peer behavior: Subjective group dynamics in minimal intergroup contexts. Child Development, 79, 444-461.

Arbuckle, J. L. (2009). Amos18 User's Guide. Chicago, IL: SPSS.

Bar-Tal, D. (1976). Prosocial behavior: Theory and research. Washington, DC: Hemisphere Publishing Corp.

Bar-Tal, D., \& Halperin, E. (2009). Overcoming psychological barriers to peace making: The influence of mediating beliefs about losses. In M. Mikulincer, \& P. R. Shaver (Eds.), Prosocial motives, emotions and behavior (pp. 431-448). Washington, DC: American Psychological Association Press.

Barber, B. K. (2009). Adolescents and war: How youth deal with political violence. New York: Oxford University Press.

Batson, C. D., Klein, T. R., Highberger, L., \& Shaw, L. L. (1995). Immorality from empathy induced altruism: When compassion and justice conflict. Journal of Personality and Social Psychology, 68, 1042-1054.

Belfast Telegraph. (2013). Man shot in legs during paramilitary style attack. Retrieved 19 June 2014, from http://www.belfasttelegraph.co.uk/news/local-national/northern-ireland/man -shot-in-legs-during-paramilitary-style-attack-29332941.html

Betancourt, T. S., Brennan, R. T., Rubin-Smith, J., Fitzmaurice, G. M., \& Gilman, S. E. (2010). Sierra Leone's former child soldiers: A longitudinal study of risk, protective factors and mental health. Journal of the American Academy of Child and Adolescent Psychiatry, 49, 606-615.

Blattmann, C. (2009). From violence to voting: War and political participation in Uganda. American Political Science Review, 103, 231-247.

Brewer, M. B. (2001). Ingroup identification and intergroup conflict: When does ingroup love become outgroup hate?. New York: Oxford University Press.

Butz, D. A., \& Plant, E. A. (2011). Approaching versus avoiding intergroup contact: The role of expectancies and motivation. In L. R. Tropp, \& R. K. Mallett (Eds.), Moving beyond prejudice reduction: Pathways to positive intergroup relations (pp. 81-98). Washington, D.C.: American Psychological Association.

Byrne, J., Conway, M., \& Ostermeyer, M. (2005). Young people's attitudes and experiences of policing, violence, and community safety in North Belfast. Belfast: Institute for Conflict Research.

Cairns, E., Kenworthy, J. B., Campbell, A., \& Hewstone, M. (2006). The role of in-group identification, religious group membership, and intergroup conflict in moderating in-group and out-group affect. The British Journal of Social Psychology, 45, 701-716.

Cameron, L., Rutland, A., Brown, R., \& Douch, R. (2006). Changing children's intergroup attitudes toward refugees: Testing different models of extended contact. Child Development, $77,1208-1219$. 
Chung-Hall, J., \& Chen, X. (2010). Aggressive and prosocial peer group functioning: Effects on children's social, school, and psychological adjustment. Social Development, 19, 659-680.

Coser, L. A. (1956). The functions of social conflict. New York: Free Press.

Cox, M. (2000). State Building and Post-Conflict Reconstruction: The Lessons from Bosnia. Geneva: CASIN.

Cummings, E. M., Davies, P. T., \& Campbell, S. B. (2000). Developmental psychopathology and family process: Theory, research, and clinical implications. New York: Guilford.

Cummings, E. M., Goeke-Morey, M. C., Schermerhorn, A. C., Merrilees, C. E., \& Cairns, E. (2009). Children and political violence from a social ecological perspective: Implications for research on children and families in Northern Ireland. Clinical Child and Family Psychology Review, 12, 16-38.

Cummings, E. M., Merrilees, C. E., Schermerhorn, A. C., Goeke-Morey, M., Shirlow, P., \& Cairns, E. (2010a). Testing a social ecological model for relations between political violence and child adjustment in Northern Ireland. Development and Psychopathology, 22, 405-418.

Cummings, E. M., Schermerhorn, A. C., Merrilees, C. M., Goeke-Morey, M. C., Shirlow, P., \& Cairns, E. (2010b). Political violence and child adjustment in Northern Ireland: Testing pathways in a social ecological model including single- and two-parent families. Developmental Psychology, 46, 827-841.

Dovidio, J. F., Gaertner, S. L., Shnabel, N., Saguy, T., \& Johnson, J. D. (2010). Recategorization and prosocial behavior: Common identity and a dual identity. In S. Sturmer \& M. Snyder (Eds.), The psychology of prosocial behavior (pp. 191-208). Malden, MA: Wiley-Blackwell.

Dovidio, J. F., \& Morris, W. N. (1975). Effects of stress and commonality of fate on helping behavior. Journal of Personality and Social Psychology, 31, 145-149.

Doyle, M. S., \& Sambanis, N. (2000). International peacebuilding: A theoretical and quantitative analysis. The American Political Science Review, 94, 779-801.

Flippen, A. R., Hornstein, H. A., Siegal, W. E., \& Weitzman, E. A. (1996). A comparison of similarity and interdependence as triggers for in-group formation. Personality and Social Psychology Bulletin, 22, 882-893.

Gaertner, S. L., \& Dovidio, J. F. (2000). Reducing intergroup bias: The common ingroup identity model. New York: Psychology Press.

Goeke-Morey, M. C., Cummings, E. M., Ellis, K., Merrilees, C. E., Schermerhorn, A. C., Shirlow, P., et al. (2009). The differential impact on children of inter- and intra-community violence in Northern Ireland. Peace and Conflict, 15, 367-383.

Hammack, P. L. (2010). Identity as burden or benefit? Youth, historical narrative, and the legacy of political conflict. Human Development, 53, 173-201.

Hewstone, M., Rubin, M., \& Willis, H. (2002). Intergroup bias. Annual Review of Psychology, 53, 575-604.

Hu, L., \& Bentler, P. M. (1999). Cutoff criteria for fit indexes in covariance structure analysis: Conventional criteria versus new alternatives. Structural Equation Modeling, 6, 1-55.

Jarman, N. (2005). Teenage kicks: Young women and their involvement in disorderly behaviour. Child Care in Practice, 11, 341-356.

Kelman, H. C. (2008). Evaluating the contributions of interactive problem solving to the resolution of ethnonational conflicts. Peace and Conflict, 14, 29-60.

Keresteš, G. (2006). Children's aggressive and prosocial behavior in relation to war exposure: Testing the role of perceived parenting and child's gender. International Journal of Behavioral Development, 30, 227-239.

Ladd, G. W., \& Profilet, S. M. (1996). The Child Behavior Scale: A teacher-report measure of young children's aggressive, withdrawn, and prosocial behaviors. Developmental Psychology, 32, 1008-1024.

Ladd, G. W., Herald-Brown, S., \& Andrews, R. K. (2009). The child behavior scale (CBS) revisited: A longitudinal evaluation of CBS subscales with children, preadolescents, and adolescents. Psychological Assessment, 21, 325-339.

Lederach, J. P. (1997). Building peace: Sustainable reconciliation in divided societies. Washington, D.C.: United States Institute of Peace Press.

Levine, M., Prosser, A., Evans, D., \& Reicher, S. (2005). Identity and emergency intervention: How social group membership and inclusiveness of group boundaries shape helping behavior. Personality and Social Psychology Bulletin, 31, 443-453. 


\section{Laura K. Taylor, Christine E. Merrilees, Marcie C. Goeke-Morey et al.}

Little, T. D., Cunningham, W. A., Shahar, G., \& Widaman, K. F. (2002). To parcel or not to parcel: Exploring the question, weighing the merits. Structural Equation Modeling, 9, 151173.

Macksoud, M. S., \& Aber, J. L. (1996). The war experiences and psychosocial development of children in Lebanon. Child Development, 67, 70-88.

Marques, J. M., Yzerbyt, V. Y., \& Leyens, J. (1988). The 'black sheep effect': Extremity of judgments towards ingroup members as a function of group identification. European Journal of Social Psychology, 18, 1-16.

McAloney, K., McCrystal, P., Percy, A., \& McCartan, C. (2009). Damaged youth, prevalence of community violence exposure and implications for adolescent well-being in post-conflict Northern Ireland. Journal of Community Psychology, 37, 635-648.

McEvoy-Levy, S. (2006). Troublemakers or Peacemakers? Youth and Post-Accord Peacebuilding. Notre Dame, IN: Notre Dame Press.

Merrilees, C. E., Cairns, E., Taylor, L. K., Goeke-Morey, M. C., Shirlow, P., \& Cummings, E. M. (2013). Social identity and youth aggressive and delinquent behaviors in a context of political violence. Political Psychology, 34, 695-711.

Meyer, E. L., Schaefer, B. A., Soto, C. M., Simmons, C. S., Anquiano, R., Brett, J., \& Worrell, F. C. (2011). Factor structure of Child Behavior Scale scores in Peruvian preschoolers. Psychology in the Schools, 48, 931-942.

Monaghan, R., \& McLaughlin, S. (2006) Informal justice in the city. Space and Polity, 10, 171-186.

Nadler, A., Harpaz-Gorodeisky, G., \& Ben-David, Y. (2009). Defensive helping: Threat to group identity, ingroup identification, status stability, and common group identity as determinants of intergroup help-giving. Journal of Personality and Social Psychology, 97, 823834.

Nesdale, D., Durkin, K., Maass, A., \& Griffiths, J. (2005). Threat, group identification, and children's ethnic prejudice. Social Development, 14, 189-205.

Nesdale, D., Maass, A., Durkin, K., \& Griffiths, J. (2005). Group norms, threat, and children's racial prejudice. Child Development, 76, 652-663.

Penner, L. A., Dovidio, J. F., Piliavin, J. A., \& Schroeder, D. A. (2005). Prosocial behavior: Multilevel perspectives. Annual Review of Psychology, 56, 365-392.

Pinto, I. R., Marques, J. M., Levine, J. M., \& Abrams, D. (2010). Membership status and subjective group dynamics: Who triggers the black sheep effect? Journal of Personality and Social Psychology, 99, 107-119. doi: 10.1037/a0018187

Pittinsky, T. L., Rosenthal, S. A., \& Montoya, R. M. (2011). Liking is not the opposite of disliking: The functional separability of positive and negative attitudes toward minority groups. Cultural Diversity and Ethnic Minority Psychology, 17, 134-143.

Police Service of Northern Ireland. (2011). Police Recorded Security Situation Statistics. Retrieved 19 June 2014 from http://www.psni.police.uk/security_stats_new_format_201011. pdf

Qouta, S., Punamäki, R., \& El Sarraj, E. (2008). Child development and family mental health in war and military violence: The Palestinian experience. International Journal of Behavioral Development, 32, 310-321.

Reicher, S., Hopkins, N., \& Condor, S. (1997). Stereotype construction as a strategy of influence (pp. 94-118). Malden: Blackwell Publishing.

Reicher, S., Cassidy, C., Wolpert, I., Hopkins, N., \& Levine, M. (2006). Saving Bulgaria's Jews: An analysis of social identity and the mobilisation of social solidarity. European Journal of Social Psychology, 36, 49-72.

Rutland, A., Abrams, D., \& Levy, S. (2007). Introduction: Extending the conversation: Transdisciplinary approaches to social identity and intergroup attitudes in children and adolescents. International Journal of Behavioral Development, 31, 417-418.

Schubotz, D., \& Robinson, G. (2006). Cross-community integration and mixing: Does it make a difference? Research Update, 1-4, 43. Retrieved 19 September 2012 from http://www .ark.ac.uk/publications/updates/

Shirlow, P., \& Murtagh, B. (2006). Belfast: Segregation, violence and the city. London: Pluto Press.

Shirlow, P., Taylor, L. K., Merrilees, C. E., Etkin, R., Goeke-Morey, M. C., \& Cummings, E. M. (2012). Sectarian hate crime: Record or perception? 
Staub, E., \& Vollhardt, J. (2008) Altruism born of suffering: The roots of caring and helping after victimization and other trauma. The American Journal of Orthopsychiatry, 78, 267-280.

Stürmer, S., \& Snyder, M. (2009). Helping 'us' versus 'them': Towards a group-level theory of helping and altruism within and across group boundaries. In S. Stürmer, \& M. Snyder (Eds.), The psychology of prosocial behavior: Group processes, intergroup relations, and helping (pp. 33-58). Oxford: Wiley-Blackwell.

Stürmer, S., Snyder, M., \& Omoto, A. M. (2005). Prosocial emotions and helping: The moderating role of group membership. Journal of Personality and Social Psychology, 88, 532546.

Tajfel, H., \& Turner, J. C. (1979). An integrative theory of intergroup conflict. In W. G. Austin, \& S. Worchel (Eds.), The social psychology of intergroup relations (pp. 33-47). Monterey, CA: Brooks/Cole.

Tam, T., Hewstone, M., Kenworthy, J., \& Cairns, E. (2009). Intergroup trust in Northern Ireland. Personality and Social Psychology Bulletin, 35, 45-59.

Tam, T., Hewstone, M., Kenworthy, J. B., Cairns, E., Marinetti, C., Geddes, L., \& Parkinson, B. (2008). Postconflict reconciliation: Intergroup forgiveness and implicit biases in Northern Ireland. Journal of Social Issues, 64, 303-320.

Taylor, L. K., Merrilees, C. E., Cairns, E., Goeke-Morey, M. C., Shirlow, P., \& Cummings, E. M. (2013). Risk and resilience: The moderating role of social coping for maternal mental health in a setting of political conflict. International Journal of Psychology, 48, 591-603.

Taylor, L. K., Merrilees, C. E., Campbell, A., Shirlow, P., Cairns, E., Goeke-Morey, M., \& Cummings, E. M. (2011). Sectarian and nonsectarian violence: Mothers' appraisals of political conflict in Northern Ireland. Peace and Conflict, 17, 343-366.

Tropp, L. R., \& Mallett, R. K. (2011). Moving beyond prejudice reduction: Pathways to positive intergroup relations. Washington D.C.: American Psychological Association.

Tropp, L. R., \& Pettigrew, T. F. (2004). Intergroup contact and the central role of affect in intergroup prejudice. In C. W. Leach, \& L. Tiedens (Eds.), The social life of emotion (pp. 246-269). Cambridge: Cambridge University Press.

Turner, J. C. (1982). Towards a cognitive redefinition of the social group. In H. Tajfel (Ed.), Social identity and intergroup relations (pp. 15-40). Cambridge: Cambridge University Press.

van der Merwe, A., \& Dawes, A. (2007). Youth violence risk assessment: gaps in local knowledge and directions for future research. Journal of Child and Adolescent Mental Health, $19,57-64$.

Van Zomeren, M., Fischer, A. H., \& Spears, R. (2007). Testing the limits of tolerance: How intergroup anxiety amplifies negative and offensive responses to out-group-initiated contact. Personality and Social Psychology Bulletin, 33, 1686-1699.

Vollhardt, J. R. (2009). Altruism born of suffering and prosocial behavior following adverse life events: A review and conceptualization. Social Justice Research, 22, 53-97.

Wallach, J. (2000). The enemy has a face: The Seeds of Peace experience. Washington, D.C.: United States Institute of Peace Press.

Walter, B. F. (2004). Does conflict beget conflict? Explaining recurring civil war. Journal of Peace Research, 41, 371-388. 